\title{
Distribution of nitrogen fractions in grazed and ungrazed fescue grassland Ah horizons
}

JOHAN F. DORMAAR, SYLVER SMOLIAK, AND WALTER D. WILLMS

\section{Abatract}

Grazing affects the plant ecology and adds excreta, thereby influencing soil $\mathbf{N}$ relationships. Consequently, total $\mathbf{N}$, mineralizable $\mathbf{N}$, exchangeable $\mathbf{N}$, hydrolyzable $\mathrm{N}$, and urease activity were assessed at the Aqriculture Canada Research Subatation, Stavely, Alberta, in the Ah horizons on rough fescue (Festuca scabrella Torr.) grasslands stocked at either light ( $0.8 \mathrm{ha} / \mathrm{AUM})$ or very heavy (0.2 ha/AUM) fixed rates for 38 years and in exclosures located within each field for an equal period of time. Even though total $N$ expressed as $t /$ ha per Ah horizon remained the same, changes in various $\mathbf{N}$ fractions were nevertheless evident. Grazing resulted in more $\mathrm{NH}_{4}^{+}-\mathrm{N}$ and $\mathrm{NO}_{3}^{-}-\mathrm{N}$ in both fields at the time of sampling and each was greater at the higher stocking rate. Although soil $N$ was lesa minerallzable, it was more scidhydrolyzable at the higher stocking rate. Urease activity also increased. The effect on soil $\mathbf{N}$ characteristics of increased excreta loads is complex and atill not well understood.

Key Worda: mineralizable nitrogen, hydrolyzable nitrogen, exchangeable nitrogen, urease activity, stocking rate

A number of previous studies on the grazing experiment sampled for the present study have been published. Johnston et al. (1971) established that very heavy grazing of fescue (Festuca scabrella Torr.) grassland range compared with light grazing changed the color of the Ah horizon from black to dark brown and the pH from 5.7 to 6.2, reduced the percent organic matter and percent total $\mathrm{P}$, but increased $\mathrm{NaHCO}_{3}$-soluble $\mathrm{P}$ and soil temperature. Total $\mathrm{N}$ remained the same, but $\mathrm{C} / \mathrm{N}$ ratios changed from 11.5 to 9.8. Soil moisture decreased with increased grazing intensity as water intake rate was reduced and, presumably, evaporation increased with the removal of litter. The potential for soil erosion by water is high when about $15 \%$ of the soil surface is bare (Johnston 1962). The soil of the very heavily grazed field was being transformed to a soil characteristic of a drier microclimate. Other than total nitrogen $(N)$ which did not show any definite trends (Johnston et al. 1971; Dormaar et al. 1977), no other forms of $N$ have been studied in this long-term grazing experiment. Urease activity in soil from an ungrazed field was less than that in soil of the very heavily grazed field (Dormaar et al. 1984).

The most important forms of available $\mathrm{N}$ are $\mathrm{NH}_{4}^{+}, \mathrm{NO}_{3}^{-}$, and certain simple organic compounds, principally those containing free amide or amino groups. The level of inorganic $\mathbf{N}$ in the soil, consisting of both $\mathrm{NO}_{3}^{-}$and $\mathrm{NH}_{4}^{+}$ions, is governed in natural ecosystems by the balance between supply from mineralization of organic $\mathbf{N}$, rain-borne $\mathrm{N}$, and fixation and losses through immobilization, leaching, volatilization, and uptake by the vegetation (Stevenson 1986). The levels are normally low because of their rapid utilization by the range vegetation. With active grazing, an additional cycle is introduced and consists of $\mathbf{N}$ passing through the animal body, after which most of it is usually returned to the soil through excreta.

Following studies of old-field successions from abandonment of

\footnotetext{
Authors are soil scientist, retired range ecologist, and range ecologist. respectively Agriculture Canada Research Station, Lethbridge, Alberta T1J 4B1. Contribution 3878768 .

Manuscript accepted 23 March 1989.
}

cultivated soils to the climax, Rice (1984) established that the amount of $\mathrm{NH}_{4}^{+}-\mathrm{N}$ increased from a minimum quantity in the first successional stages to a maximum in the climax and vice versa for $\mathrm{NO}_{3}^{-}-\mathrm{N}$. Further, Dormaar (1988) observed that the quality of the soil organic matter and, possibly, of root exudates may affect the formation of $\mathrm{NH}_{4}^{+}-\mathrm{N}$ and $\mathrm{NO}_{3}^{-}-\mathrm{N}$. Grazing changes the vegetation composition and the chemical characteristics of soil (Johnston et al. 1971) but its effect on the mineral $N$ status is not clear. Nitrogen is a key element in the grassland ecosystem, because of its capacity to limit primary and secondary production. A study was made to determine the effects of grazing on the composition and quantity of nitrogen in the Ah horizon of the rough fescue grasslands and to assess the consequences of the effects.

\section{Materials and Methods}

The study site was at the Agriculture Canada Research Substation, Stavely, Alberta, situated in the Porcupine Hills, an area managed primarily for grazing by cattle. The vegetation is typical of the Fescue Grassland Association (Coupland and Brayshaw 1953). The soils are members of the Orthic Black Subgroup of the Chernozemic Order (Udic Haploboroll), developed on till overlying sandstone, and have a clay-loam to loam texture. The climate is dry subhumid and annual precipitation averages about $500 \mathrm{~mm}$. Details of the overall grazing trial since 1949 have been given by Johnston et al. (1971) and Willms et al. (1985).

On 15 Oct. 1986, 2 fields grazed by cows with calves since 1949 and adjacent exclosures were selected for sampling. The fields were grazed each year from about 15 May to 15 Nov. The lightly stocked field (field $L$ ) was at a rate of 0.8 ha per animal unit month (AUM) and the very heavily stocked field (field $\mathrm{VH}$ ) at the rate of 0.2 ha/AUM. The grazing season of the latter field, because of deterioration of cover, varied from about 2.5 to 5 months since 1962. Cattle removed about 25 and $80 \%$ of available forage in fields $L$ and $\mathrm{VH}$, respectively.

Soil pits were dug and soil profiles were described at each site. In addition, the Ah horizon was sampled in 4 subplots in fields $L$ and VH which were paired with 4 subplots in the exclosures within the same fields, giving a total of 16 samples. The paired plots had similar slope and aspect thereby reducing variability due to site. Only the Ah horizon was sampled because over $70 \%$ of the root system can be found here (Coupland and Brayshaw 1953). Even though organic matter and nitrogen levels fluctuate with the seasons (Dormaar et al. 1977, Dormaar et al. 1984), the sampling was made in autumn because the effects of excreta and trampling would be at their peak. The sampling period was similar to that reported by Johnston et al. (1971) as part of a study examining grazing effects on soils.

The samples were hand-sieved through a $2-\mathrm{mm}$ sieve the day they were collected. A portion of each sieved sample was stored in sealed, double polyethylene bags at $4^{\circ} \mathrm{C}$; the remainder was dried and ground to pass a $0.5-\mathrm{mm}$ sieve. At the time of sieving, roots and other debris were removed from the soil and discarded. Moisture content of the soil was determined by drying a small portion overnight at $105^{\circ} \mathrm{C}$. The mineralizable $\mathrm{N}$ analyses were carried out 
on the moist soil. All other analyses were carried out on the air-dried soils.

Urease activity, which is important as a decomposing agent for urea, was determined at pH 9.0 by incubating $5 \mathrm{~g}$ with tris(hydroxymethyl)-aminomethane buffer $(0.05 \mathrm{M})$, urea solution, and toluene at $37^{\circ} \mathrm{C}$ for 2 hours, and measuring the ammonium released after steam distillation (Tabatabai and Bremner 1972). Total $N$ was determined by the method outlined by the Association of Official Agricultural Chemists (1950) and hydrolyzable $\mathrm{N}$, amino acid-N, amino sugar- $\mathrm{N}$ and $\mathrm{NH}_{\mathbf{9}}-\mathrm{N}$ by methods described by Stevenson (1982). The relative ability of the soils to mineralize the $\mathbf{N}$ from the organic matter was determined as outlined by MacKay and Carefoot (1981); exchangeable $\mathrm{NO}_{5}^{-} \mathrm{N}$ and $\mathrm{NH}_{4}^{+} \mathrm{N}$ by $\mathrm{KCl}$ extraction and steam distillation were as outlined by Keeney and Nelson (1982). All analytical results were expressed on the basis of ovendried weight of soil.

The data were analyzed as if there were 4 treatments with 4 replications using a one-way analysis of variance, with the assumption that the sampling error represented the experimental error. Single degree of freedom contrasts (Steel and Torrie 1980) were used to test for differences between selected means.

Although replication and application of current statistical analyses to newly established, replicated field plot experiments is common and undeniably desirable and useful, valid information and data can still be gained from early established, unreplicated field experiments including long-term grazing trials, by virtue of their antiquity (Ridley and Hedlin 1968, Dormaar and Pittman 1980).

\section{Results}

Soil profiles were up to $69 \mathrm{~cm}$ thick (Table 1), and gravel to cobble size quartzitic stones were present throughout the profile together with sandstone ghosts in the lower $\mathrm{Bm}_{2}$ and $\mathrm{Ck}$ horizons.

Table 1. Pedon description of the Orthic Black Chernozemic (Udic Haploboroll) soll at the Agriculture Canada Research Subatation, Stavely, Alberta.

\begin{tabular}{|c|c|c|}
\hline Horizon & Thickness (cm) & \\
\hline $\mathbf{A h}$ & 14 to 20 & $\begin{array}{l}\text { Black (10YR } 2 / 1 \text {, moist) clay loam; } \\
\text { moderate fine granular; soft, very } \\
\text { friable; abundant fine to medium ran- } \\
\text { dom roots; tongued boundary; mildly } \\
\text { acidic. }\end{array}$ \\
\hline $\mathbf{B m}_{1}$ & 8 to 21 & $\begin{array}{l}\text { Dark yellowish brown (10YR } 3 / 4 \text {, } \\
\text { moist) clay loam; weak, fine sub- } \\
\text { angular blocky; slightly hard; fewer, } \\
\text { fine to medium vertical roots; diffuse } \\
\text { boundary; neutral. }\end{array}$ \\
\hline $\mathrm{Bm}_{2}$ & 12 to 20 & $\begin{array}{l}\text { Dark yellowish brown (10YR } 4 / 4 \text {, } \\
\text { moist) loam to clay loam; moderate } \\
\text { coarse, prismatic to subangular } \\
\text { blocky; firm; few very fine, vertical } \\
\text { roots; abrupt, wavy boundary; } \\
\text { neutral. }\end{array}$ \\
\hline Ck & 8 & $\begin{array}{l}\text { Yellowish brown (10YR } 5 / 4 \text {, moist) } \\
\text { with very pale brown (10YR } 8 / 3 \text {, } \\
\text { moist) clay loam; angular blocky; } \\
\text { friable; strongly effervescent; few } \\
\text { roots; mildly alkaline. }\end{array}$ \\
\hline
\end{tabular}

With progressive transformation of the soil due to increased grazing pressure, the color of the Ah horizon in field VH changed from black (10YR $2 / 1$, dry) to dark brown (10YR 3/3, dry) indicating a loss of organic matter. The average water content of the Ah horizons of the soils in the exclosures, field $\mathrm{L}$, and field $\mathrm{VH}$, at the time of sampling, was 64,59 , and $52 \%$ (w/w), respectively. Between 15 Sept. and 14 Oct.1986, $92 \mathrm{~mm}$ of precipitation occurred in the form of rain and wet snow.

The $\mathbf{N}$ characteristics of the samples from the 2 exclosures were similar in each comparison ( $P>0.40$ ) even though, geographically, one exclosure was in an upslope and the other was in a midslope position. Therefore, their data were combined for comparisons with the grazed fields (Table 2).

Total $N$, exchangeable $N$, hydrolyzable $N$, and urease activity in soils increased with grazing intensity, while mineralizable $\mathbf{N}$ and amino sugar decreased (Table 2). Soils of the exclosure were similar, with respect to total $N$ and amino sugar, to the soil of field $L$.

\section{Discussion}

Willms et al. (1985) noted that prior to the initiation of the grazing study in 1949, the area was moderately stocked for summer grazing with cattle from 1884 to 1908 , with horses from 1908 to 1920, and with cattle again from 1920 to 1943 . The latter period, however, included heavy use during the 1930's drought. Finally, the area was used lightly for winter pasture from 1944 to 1949 . In 1949 , when this study was started, exclosures were established. Even though the range condition in the exclosure of field $L$ had reached near stability 14 years later in a level upslope position and the range condition in the exclosure of field $\mathrm{VH}$ was still improving in 1981 due to its steep midslope position (Willms et al. 1985), the soil profile descriptions of the 2 exclosures were now quite similar. In addition, the soil characteristics measured were in the same steady state. The changes in color and depth of the Ah horizons, as noted by Johnston et al. (1971), and the changes in the various $N$ parameters measured (Table 2), thus represent either an intensification or an amelioration of the characteristics existing in 1949 by the grazing scheme imposed.

Soil samples were not taken at the start of the present grazing study in 1949. The first samples analyzed were in 1967 (Johnston et al. 1971); however, the exclosures were not sampled and bulk densities were not determined at that time. Total $\mathrm{N}$ at that time was 0.59 and $0.57 \%$ for fields $\mathrm{L}$ and $\mathrm{VH}$, respectively. These values were the averages of 10 samples randomly selected from grids superimposed on these fields. Of these samples, those closest to and in equal positions to the sites sampled in 1986, averaged 0.78 and $0.79 \% \mathrm{~N}$ for field $\mathrm{L}$ and $\mathrm{VH}$, respectively (Table 3 ). Even though both fields appeared to gain in $\mathbf{N}$, the corresponding $\mathrm{C} / \mathrm{N}$ values for fields $\mathrm{L}$ and VH were generally not out of line (Table 3 ).

Since the increase in percent $\mathrm{N}$ cannot be explained and may be attributed to a sampling discrepancy between 1967 and 1986, it is more meaningful to compare the $\mathrm{N}$ of the exclosures with that of field VH as found at the time of sampling in 1986. For this comparison, $\mathbf{N}$ mass in the Ah horizon is a more realistic parameter because it accounts for the depth of the Ah horizon and the concentration of $\mathbf{N}$ which has, presumably, reached equilibrium with the grazing regime imposed on it.

Concentration of $\mathrm{N}$ per se in the $\mathrm{Ah}$ horizon cannot explain the effects of grazing soil quality since erosion of the Ah horizon and its bulk density had also been affected. However, on the basis of the $\mathbf{N}$ concentrations, depth of Ah horizons and the bulk densities, the Ah horizons in the exclosure and under the VH field contained 12.96 and $13.07 \mathrm{t} /$ ha of $\mathrm{N}$, respectively (Table 3). Although grazing animals ingest a large amount of $\mathrm{N}$ in feed, about 75\% is excreted (Peterson et al. 1956). The $\mathrm{N}$ was, therefore, concentrated in a more dense Ah horizon of the VH field. Similarly, the mass of $\mathrm{N}$ in $\mathrm{t} / \mathrm{ha}$ for field $\mathrm{L}$ was 12.94 (Table 3 ). Hence, rather than using concentrations, the focus has been on more meaningful biochemical parameters to examine the effect of increased grazing pressures on the quality of the soil, i.e., the redistribution of the $\mathrm{N}$ within the system. 
Table 2. Some nitrogen characteriatics of the Ah horizons of a Black Chernozemic soll, wampled $150 \mathrm{Cet} .1986$, from 2 fields stocked at elther light or very heavy rates and from their exclosures $(n=4)$.

\begin{tabular}{|c|c|c|c|c|c|c|}
\hline & \multirow{2}{*}{$\begin{array}{c}\text { Exclosures } \\
\text { (E) }\end{array}$} & \multicolumn{2}{|c|}{ Stocking rate 1} & \multicolumn{2}{|c|}{ Contrasts } & \multirow[b]{2}{*}{ L vs. VH } \\
\hline & & $\mathbf{L}$ & VH & E vs. L & E vs. VH & \\
\hline$\overline{\text { Total N (\%) }}$ & 0.93 & 0.94 & 1.10 & 0.55 & $<0.01$ & $<0.01$ \\
\hline Mineralizable $N(\mu \mathrm{g} / \mathrm{g} \text { of soil })^{2}$ & 73.9 & 66.2 & 49.8 & $<0.01$ & $<0.01$ & $<0.01$ \\
\hline $\begin{array}{l}\text { Exchangeable } N(\mu \mathrm{g} / \mathrm{g}) \\
\mathrm{NH}^{+}-\mathrm{N} \\
\mathrm{NO}_{-}^{-} \mathrm{N}\end{array}$ & $\begin{array}{l}9.2 \\
4.56\end{array}$ & $\begin{array}{c}12.9 \\
6.72\end{array}$ & $\begin{array}{l}18.3 \\
10.90\end{array}$ & $\begin{array}{l}<0.01 \\
<0.01\end{array}$ & $\begin{array}{l}<0.01 \\
<0.01\end{array}$ & $\begin{array}{l}<0.01 \\
<0.01\end{array}$ \\
\hline $\begin{array}{l}\text { Hydrolyzable } \mathbf{N}(\% \text { of total } N \text { ) } \\
\text { Total } \\
\text { Amino acid } \\
\text { Amino sugar } \\
\text { Ammonium }\end{array}$ & $\begin{array}{c}74.9 \\
25.2 \\
8.0 \\
23.5\end{array}$ & $\begin{array}{r}82.5 \\
27.5 \\
7.2 \\
32.8\end{array}$ & $\begin{array}{r}85.0 \\
30.2 \\
6.0 \\
36.2\end{array}$ & $\begin{array}{r}<0.01 \\
0.04 \\
0.34 \\
<0.01\end{array}$ & $\begin{array}{r}<0.01 \\
<0.01 \\
0.02 \\
<0.01\end{array}$ & $\begin{array}{l}0.06 \\
0.03 \\
0.18 \\
0.01\end{array}$ \\
\hline Urease activity ${ }^{3}$ & 252 & 316 & 410 & $<0.01$ & $<0.01$ & $<0.01$ \\
\hline
\end{tabular}

ILight (L) - stocked at 0.8 ha/AUM; Very Heavy (VH) - stocked at 0.2 ha/AUM.

${ }^{2}$ Change of $\left(\mathrm{NH}_{4}^{+}+\mathrm{NO}_{3}\right)-\mathrm{N}$ from 2 successive incubations at 1 and 2 wk periods.

${ }^{3} \mathrm{NH}$ i-N released, $\mu \mathrm{g} / \mathrm{g}$ of dry soil per 2 hours.

Table 3. C/N ratios and total N per Ah horizon of a Black Chernozemic soil, sampled 15 Oet. 1986, from 2 fields stocked at elther light or very heavy rates and from their excloaures $(n=4)$.

\begin{tabular}{|c|c|c|c|c|c|}
\hline & \multirow{2}{*}{$\begin{array}{c}\text { Exclosures } \\
1986^{2}\end{array}$} & \multicolumn{4}{|c|}{$\begin{array}{l}\text { Stocking Ratel } \\
\text { L }\end{array}$} \\
\hline & & 1967 & 1986 & 1967 & 1986 \\
\hline $\begin{array}{l}\text { Organic C (\%) } \\
\text { Total N (\%) } \\
\text { C/N } \\
\text { Depth Ah }(\mathrm{cm}) \\
\text { Bulk density }\left(\mathrm{Mg} / \mathrm{m}^{3}\right) \\
\text { Total } \mathrm{N} \text { in } \mathrm{Ah}(\mathrm{t} / \mathrm{ha})\end{array}$ & $\begin{array}{l}10.4 \\
0.93 \\
11.2 \\
17 \\
0.82 \\
12.96\end{array}$ & $\begin{array}{c}9.0 \\
0.78 \\
11.5\end{array}$ & $\begin{array}{c}10.4 \\
0.94 \\
11.1 \\
16 \\
0.86 \\
12.94\end{array}$ & $\begin{array}{c}8.6 \\
0.79 \\
10.9\end{array}$ & $\begin{array}{c}8.1 \\
1.10 \\
7.4 \\
12 \\
0.99 \\
13.07\end{array}$ \\
\hline
\end{tabular}

'Light (L) - stocked at 0.8 ha/AUM; Very Heavy (VH) - stocked at 0.2 ha/AUM. 2Percent $\mathrm{C}$ and $\mathrm{N}$ and bulk density were not determined in the exclosures in the 1967 study (Johnson et al. 1971).

The increased grazing pressure resulting from the high stocking rate has altered the $\mathrm{N}$ properties of the range soil. Part of this can be related to the increased excreta load. For example, the excretarelated parameters, such as available N(MacDiarmid and Watkin 1972), increased in the grazed areas. Although the mineralizable N, i.e., the potential availability of $\mathbf{N}$, of the whole soil was lower in the grazed than in the ungrazed soils (Table 2), dung $N$ per se has been found to be a very efficient nutrient for plant growth because of its slow-release availability (MacDiarmid and Watkin 1972). Urease activity similarly increased in the very heavily grazed range.

Since there is less mulch and less standing biomass under the very heavily grazed regime, the soil warms up quicker in the spring (Johnson 1962, Johnston et al. 1971) and will be drier (Johnston et al. 1971, Dormaar et al. 1989). There is more $\mathrm{NH}_{4}^{+}-\mathrm{N}^{2}$ than $\mathrm{NO}_{3}^{-}-\mathrm{N}$ in rough fescue grassland than in grassland associations of semiarid areas. Nevertheless, in this experiment, concentrations of both forms of nitrogen increased with intensity of grazing. Bauer et al. (1987) noted that the difference between ungrazed and grazed levels of soil $\mathbf{N}$ could be caused by greater denitrification losses in ungrazed grasslands because of cooler and more moist conditions early in the season. Naturally, with more standing crop, more $\mathbf{N}$ will be taken up as well.

A decrease in mineralization rate was to be expected for several reasons. It has been shown that the Black Chernozemic soil under increased grazing pressures changes to a soil characteristic of a drier microclimate (Johnston et al. 1971). Neal (J.L. Neal, Jr., unpublished data) found that soil microbial mass decreases from the dry, subhumid to the semiarid climate of southern Alberta and from field $\mathrm{L}$ to field $\mathrm{VH}$. Finally, over $90 \%$ of $\mathrm{N}$ in most surface soils is organically combined (Stevenson 1986). However, 3 other factors will have to be considered in this context as well. With heavy grazing, the quality of the soil organic matter has changed, since, in spite of increased total $\mathbf{N}$ content, this $\mathbf{N}$ was not as potentially available. Herbage removal resulted in considerable reduction in weight of roots (Johnston 1961) and thus in root exudates. There is also evidence (Neal 1969) that roots of increasing and invading plants on overgrazed grasslands produce substances that inhibit nitrification. This could be a mechanism whereby these plants conserve the low amounts of nitrogen available in grassland soils. The $\mathrm{NH}_{4}^{+}-\mathrm{N}$ uptake characteristics of these increasers and invaders are, however, virtually unknown. Finally, the chemistry of the pathways of decomposition of the excreta under the influence of the changing microclimate and the root exudates of the increasers and invaders has not been studied in much detail.

Although Sowden et al. (1977) showed that between 86 and $89 \%$ of the total $\mathbf{N}$ in soils from widely differing climatic zones was hydrolyzable by hot $6 \mathrm{M} \mathrm{HCl}$, the range for this study was 75 to $85 \%$. For a sequence of native range to recently revegetated native range on an Orthic Brown Chernozemic (Aridic Ustochrept) soil, this range was 75 to $81 \%$ (Dormaar and Smoliak 1985). As grazing pressure increased, the fraction of the hydrolyzable $\mathrm{N}$ presented as amino acid- $\mathrm{N}$ and $\mathrm{NH}_{3}-\mathrm{N}$ gradually increased, while the proportion as amino sugar- $\mathrm{N}$ essentially remained the same. Some of the $\mathrm{NH}_{3}-\mathrm{N}$ will be derived from indigenous fixed $\mathrm{NH}_{4}^{+} \mathrm{N}$ and part comes from partial destruction of amino sugars (Stevenson 1982). Nevertheless, the composition of a large percentage of the $\mathrm{N}$ in the soil is still unknown. Schnitzer and Hindle (1981) felt that the unidentified $\mathbf{N}$ was not proteinaceous, because relatively more 'unknown' $\mathrm{N}$ occurred in the inorganic than in the organic fraction of the soil.

Models of $\mathbf{N}$ cycling and $\mathbf{N}$ budgets have tried to account for soil $\mathrm{NH}_{4}^{+}-\mathrm{N}$ and $\mathrm{NO}_{3}^{-}-\mathrm{N}$, soil organic matter, and $\mathrm{N}$ content of aboveand below-ground biomass together with the actual plant, microorganisms, and soil interactions (Parton and Risser 1977). However, more detailed analyses of the Ah horizon subjected to various grazing pressures, in terms of the organic and inorganic composition of excreta and root exudates of decreasers, increasers, and invaders, will be necessary to expand these models in order to account for the accompanying plant ecological and microclimatological transformation.

Even though concentrations of total and exchangeable $\mathrm{N}$ increased, the decrease in mineralizable and thus potentially avail- 
able $\mathrm{N}$ decreased with grazing intensity. This change is real regardless of the time of sampling. Nevertheless, in a study of this nature, time of sampling may be crucial. Time and extent of availability are essential parameters for optimal plant growth. However, different plants have different $\mathrm{N}$ requirements, both in terms of timing and of $\mathrm{NO}_{3}^{-}$or $\mathrm{NH}_{4}^{+}$requirements. Rough fescue is largely eliminated by very heavy grazing, while the new grasses and forbs will have different needs that fit the new ecological niche created by overgrazing and increased excreta load.

\section{Literature Cited}

Asachation of Onchal Agricuitural Chemiats. 1950. Official methods of analysis. 7th ed., Washington, D.C.

Baver, A., C.V. Cole, and A.L. Black. 1987. Soil property comparisons in virgin grasslands between grazed and nongrazed management systems. Soil Sci. Soc. Amer. J. 51:176-182.

Coupland, R.T., and F.C. Brayshaw. 1953. The fescue grassland of Saskatchewan. Ecology 34:386-405.

Dorman, J.F. 1988. Effect of plant roots on chemical and biochemical properties of surrounding discrete soil zones. Can. J. Soil Sci. 68:233-242.

Dormar, J.F., A. Johnaton, and S. Smoliak. 1977. Seasonal variation in chemical characteristics of soil organic matter of grazed and ungrazed mixed prairie and fescue grassland. J. Range Manage. 30:195-198.

Dormaar, J.F., A. Johnston, and S. Smoliak. 1984. Seasonal changes in carbon content, and dehydrogenase, phosphatase, and urease activities in mixed prairie and fescue grassland Ah horizons. J. Range Manage. 37:31-35.

Dormasa, J.F., and U.J. Pttman. 1989. Decomposition of organic residues as affected by various dryland spring wheat-fallow rotations. Can. J. Soil. Sci. 60:97-106.

Dormaar, J.F., and S. Smoliak. 1985. Recovery of vegetative cover and soil organic matter during revegetation of abandoned farmland in a semiarid climate. J. Range Manage. 38:487-491.

Dormanr, J.F., S. Smolink, and W.D. Willms. 1989. Vegetation and soil responses to short-duration grazing on Fescue Grasslands. J. Range Manage. (in press).

Johnaton, A. 1961. Comparison of highly grazed and ungrazed range in the Fescue Grassland of southwestern Alberta. Can. J. Plant Sci. 41:615-622.
Johnuton, A. 1962. Effects of grazing intensity and cover on the waterintake rate of Fescue Grassland. J. Range Manage. 15:79-82.

Johnoton, A., J.F. Dorman, and S. Smollak. 1971. Long-term grazing effects on Fescue Grassland soils. J. Range Manage. 24:185-188.

Keeney, D.R., and D.W. Nelson. 1982. Nitrogen-Inorganic forms. In: A.L. Page (ed.), Methods of soil analysis. Part 2. Chemical and microbiological properties. Agron. 9:643-698. Amer. Soc. Agron., Madison, Wis.

MacDiarmid, B.N., and B.R. Watkin. 1972. The cattle dung patch. 2. Effect of a dung patch on the chemical status of the soil, and ammonia nitrogen losses from the patch. J. Brit. Grassl. Soc. 27:43-48.

MacKay, D.C., and J.M. Carefoot. 1981. Control of water content in laboratory determination of mineralizable nitrogen in soils. Soil Sci. Soc. Amer. J. 45:444-446.

Neal, Jr., J.L. 1969. Inhibition of nitrifying bacteria by grass and forb root extracts. Can. J. Microbiol. 15:633-635.

Parton, W.J., and P.G. Riscer. 1977. Nigrogen cycling in a true prairie. Bull. Ecol. Soc. Amer. 58:7.

Petercen, R.G., W.W. Woodhouse, Jr., and H.L. Lncas. 1956. The distribution of excreta by freely grazing cattle and its effect on pasture fertility: II. Effect of returned excreta on the residual concentration of some fertilizer elements. Agron. J. 48:444-449.

Rice, N.L. 1984. Allelopathy. 2nd ed. Academic Press, Inc., New York.

Ridley, A.D., and R.A. Hedlin. 1968. Soil organic matter and crop yields as influenced by the frequency of summerfallowing. Can. J. Soil Sci. 48:315-322.

Sehnitzer, M., and D.A. Hindle. 1981. Effects of different methods of acid hydrolysis on the nitrogen distribution in two soils. Plant Soil 60:237-243.

Sowden, F.J., Y. Chen, and M. Sehnitzer. 1977. The nitrogen distribution in soils formed under widely differing climatic conditions. Geochim. Cosmochim. Acta. 41:1524-1526.

Steel, R.G.D., and J.H. Torrie. 1989. Principles and procedures of statistics. A biometric approach. 2nd ed. McGraw-Hill Book Co., Toronto.

Stevenson, F.J. 1982. Nitrogen-Organic forms. In: A.L. Page (ed.), Methods of soil analysis. Part 2. Chemical and microbiological properties. Agron. 9:625-641. Amer. Soc. Agron., Madison, Wis.

Stevenson, F.J.1986. Cycles of soil carbon, nitrogen, phosphorus, sulphur, micronutrients. John Wiley \& Sons Inc., New York.

Tabatabai, M.A., and J.M. Bremner. 1972. Assay of urease activity in soils. Soil Biol. Biochem. 4:479-487.

Willms, W.D., S. Smolink, and J.F. Dormanr. 19s5. Effects of stocking rate on a Rough Fescue Grassland vegetation. J. Range Manage. 38:220-225.

\section{SRM Election Results}

The Elections Committee, along with several other Colorado

Section members, counted the ballots for new officers at the Society for Range Management headquarters. Elected officers are:

Second Vice President-John L. "Jack" Artz

Directors (1989-1991)-Murray L. Anderson and Will H. Blackburn

Directors Anderson and Blackburn will replace retiring Directors Samuel and Sanders in February 1990.

The amendment to the Bylaws regarding Emeritus Membership was approved.

Ballots and tally sheets are retained in the Denver office for one year for review. Approximately $31 \%$ of the membership voted. 